Економічні науки: збірник наукових праць Луцького національного технічного університету. Серія "Регіональна економіка". Випуск 18 (71). Редкол.: відп. ред. д.е.н., професор Л.Л. Ковальська. Луиьк: ІВВ Луиького НТУ, 2021. 278 с.

УДК 339.944:004.9

Кривов’ язюк І.В., к.е.н., професор

Луцький національний технічний університет

\title{
МІЖНАРОДНІ СТРАТЕГІЧНІ АЛЬЯНСИ В ІТ-БІЗНЕСІ: РЕГІОНАЛЬНИЙ АСПЕКТ
}

В статті вирішено складне наукове завдання - поглиблення дослідження регіональних аспектів IT-бізнесу, що здійснюється в межах міжнародних стратегічних альянсів. Критичний аналіз наукових публікацій вітчизняних i зарубіжних учених сучасності дозволив розкрити особливості співпраці міжнародних стратегічних альянсів у сфері IT-бізнесу, визначити важливість і вагомість ролі регіональних альянсів. Проаналізовано показники розвитку ITбізнесу в період поширення пандемії COVID-19 та визначено розподіл ринку інформаційно-комунікаційних технологій за регіонами світу, визначено перспективність розвитку цього ринку для компаній країн Близького Сходу. Розкрито регіональний розподіл стратегічних альянсів в країнах ЄС. Виявлено тенденцію децентралізації у формуванні європейського ринку стратегічних альянсів у період, що передує поширенню пандемії COVID-19. Вказано на важливість врахування системи факторів мотивування створення та розвитку міжнародних стратегічних альянсів у IT-сфері.

Ключові слова: міжнародний стратегічний альянс (MCA), інформаційно-комунікаційні технології (ІКТ), ІТ-бізнес, регіональний аспект.

\section{Kryvovyazyuk I.V.}

\section{INTERNATIONAL STRATEGIC ALLIANCES IN IT- BUSINESS: A REGIONAL ASPECT}

At the present stage of international business development, the issues of mutually beneficial cooperation between companies, which is provided based on the distribution and coordination of general principles of management, benefits and costs, the creation of new value for companies, are becoming increasingly important. Such cooperation between companies in the IT field is especially important, because it aims to maintain greater share of autonomy, achieve new goals, expand the customer base, improve the quality of provided services, allows receiving financial assistance, the effectiveness of which depends on the chosen types of organizational design of relationships of the international strategic alliances and ways of their management, helping to reduce pressure from competitors, reduce risks, improve the exchange of modern technologies.

Critical analysis of scientific publications of modern domestic and foreign scientists allowed to reveal the peculiarities of cooperation of ISA in the field of IT business, note the prospects of joining such alliances by Ukrainian companies, 
Економічні науки: збірник наукових праць Луцького національного технічного університету. Серія "Регіональна економіка". Випуск 18 (71). Редкол.: відп. ред. д.е.н., професор Л.Л. Ковальська. Луиьк: ІВВ Луцьького НТУ, 2021. 278 с.

emphasize the importance of taking into account the role of ISA in developing competitive strategies of domestic enterprises in the IT sector, to determine the factors of ISA formation, their advantages and disadvantages. The importance and significance of the role of regional alliances, operational coordination of IT business in inter-operational relations, strategic IT opportunities, and peculiarities of management in global, regional and local production and sales chains of implementation of IT services are also determined.

The indicators of IT business development during the spread of the COVID-19 pandemic are analysed and the distribution of the information and communication technologies market by regions of the world is determined, the key role of ISA companies from the USA, EU and China is indicated. Determined prospects for the development of this market for companies in the Middle East which will be achieved through government initiatives in the field of digital transformation and adoption by companies of revolutionary technologies such as artificial intelligence and the Internet of Things, development of a portfolio of ICT services for corporations, including programs to monetize investments in $5 \mathrm{G}$ network, cloud computing, cybersecurity, block chain, etc.

The regional distribution of strategic alliances in the EU countries is revealed. The tendency of decentralization in the formation of the European market of strategic alliances in the period preceding the spread of the COVID-19 pandemic is revealed as well. It was found that for almost all studied countries the average values of the ESA number are much lower than the average values of the number of ISA. That is, companies in European countries are more focused on creating strategic alliances with companies of other regions of the world.

The importance of taking into account the system of factors motivating the creation and development of ISA in the IT field is indicated, in particular the adjacency of high-tech industries and sectors of business partners, taking into account the conditions of COVID-19 spread, the coherence of strategic goals of partners before and after COVID-19 spread, the interchangeability of methods and forms of work in the market depending on the conditions of COVID-19 spread, the speed of business diversification regarding the spread of the pandemic and introduced quarantine restrictions in partner countries, compliance of partners' contributions to the scale of business during the pandemic; strengthening operational integration as the strategic alliance develops.

Key words: international strategic alliance (ISA), information and communication technologies (ICT), IT-business, regional aspect.

Кривовязюк И.В.

\section{МЕЖДУНАРОДНЫЕ СТРАТЕГИЧЕСКИЕ АЛЬЯНСЫ В ИТ-БИЗНЕСЕ: РЕГИОНАЛЬНЫЙ АСПЕКТ}

В статье решено сложная научная задача - углубление исследования региональных аспектов ИТ-бизнеса, которое осуществляется в рамках международных стратегических альянсов. Критический анализ научных 
Економічні науки: збірник наукових праць Луцького національного технічного університету. Серія "Регіональна економіка". Випуск 18 (71). Редкол.: відп. ред. д.е.н., професор Л.Л. Ковальська. Луцьк: ІВВ Луцького НТУ, 2021. 278 с.

публикаций отечественных и зарубежных ученых современности позволил раскрыть особенности сотрудничества международных стратегических альянсов в сфере ИТ-бизнеса, определить важность и значимость роли региональных альянсов. Проанализированы показатели развития ИТ-бизнеса в период распространения пандемии COVID-19 и определено распределение рынка информационно-коммуникационных технологий по регионам мира, определена перспективность развития этого рынка для компаний стран Ближнего Востока. Раскрыто региональное распределение стратегических альянсов в странах ЕС. Выявлена тенденция децентрализации в формировании европейского рынка стратегических альянсов в период, предшествующий распространению пандемии COVID-19. Указано на важность учета системы факторов мотивации создания и развития международных стратегических альянсов в ИТ-сфере.

Ключевые слова: международный стратегический альянс (МСA), информационно-коммуникационные технологии (ИКТ), ИТ-бизнес, региональный аспект.

\section{Постановка проблеми у загальному вигляді та їі} зв'язок 3 важливими науковими й практичними завданнями. В сучасних умовах господарювання все більшої ваги набувають питання взаємовигідного співробітництва між міжнародними компаніями, що забезпечується на основі розподілу та узгодження загальних засад управління, вигід i витрат, створення нової цінності для компаній. Таке співробітництво між компаніями в IT-сфері $\epsilon$ особливо важливим, адже спрямоване на збереження більшої частки автономії, досягнення нових цілей, розширення бази клієнтів, поліпшення якості наданих послуг, дозволяє отримувати фінансову допомогу тощо [1, с. 55-56], результативність яких залежить від обраних видів організаційного оформлення відносин МСА i способів їх менеджменту [2, с. 16-18], сприяючи зменшенню тиску зі сторони конкурентів, зниженню ризиків, покращенню обміну сучасними технологіями. В умовах поширення COVID-19, аналіз наявної динаміки та прогнозування світових витрат на IT, вказують на значне підвищення інтересу до секторів IT-бізнесу [3], особливо за обставин зростання краху бізнесу в багатьох сферах під тиском пандемії [4, с. 179-184], що підкреслює значимість досліджуваної проблематики в напрямку вирішення важливих наукових і практичних завдань. 
Економічні науки: збірник наукових праць Луцького національного технічного університету. Серія "Регіональна економіка". Випуск 18 (71). Редкол.: відп. ред. д.е.н., професор Л.Л. Ковальська. Луиьк: ІВВ Луиького НТУ, 2021. 278 с.

Аналіз останніх досліджень і публікацій, у яких започатковано вирішення проблеми. Досліджувана проблематика широко представлена в наукових доробках як вітчизняних, так і зарубіжних учених. Зокрема, Дугінець Г. i Ніжейко К. розкривають особливості співпраці MCA у IT-сфері та відзначають перспективність вступу до таких альянсів українських компаній [5, с. 35-47], проте недостатню увагу приділили питанням доцільності здійснення такої взаємодії. Габрелян А.Ю., відзначаючи зростання взаємозалежності компаній у сфері інформаційних технологій, підкреслює значимість врахування ролі МСА при розробці конкурентних стратегій вітчизняних підприємств IT-сфери [6, с. 469-478], однак результати його досліджень здійснено у прековідний період, відтак дещо втратили свою актуальність. Такі вчені як Орлов В.М., Петрашевська А.Д., Драган К. Ю., Статірова К.В. визначають фактори формування МСА, їх переваги та недоліки, особливості формування синергетичного ефекту компаній партнерів по альянсу [7], але меншою мірою стосуються аналізу діяльності ІТ-сфери. Максименко І.Я. та Єфімова М.О., порівнюючи особливості формування МСА на вітчизняному та міжнародному ринках, підкреслюють їх значення для реалізації окремих науково-виробничих проєктів, угод про співпрацю, ліцензійних угод, угод про спільні розробки та дослідження, виробництво на основі пайової участі в статутному капіталі компанії-партнера тощо [8]. Про зростання ролі IT-бізнесу для міжнародних ринків йдеться в [9]. Натомість, про важливість i вагомість ролі регіональних альянсів йдеться в роботах таких зарубіжних учених як Abraha D. and Hyder A.S., що розкрили особливості трансформації стратегічних альянсів на ринках країн, що розвиваються [10]; Trang S., Mandrella M., Marrone M. тa Kolbe L. M., які зосередили увагу на дослідженні ролі оперативного узгодження IT-бізнесу в міжопераційних відносинах, використовуючи вибірку 3241 регіонального сіткового об' єкта [11]; Panda S., ще раз підкреслюючи стратегічні IT-можливості, вказує на обмежувальний вплив COVID-19 [12]; Keijser Ch., Belderbos R., Goedhuys М. визначають особливості 
Економічні науки: збірник наукових праць Луцького національного технічного університету. Серія "Регіональна економіка". Випуск 18 (71). Редкол.: відп. ред. д.е.н., професор Л.Л. Ковальська. Луиьк: ІВВ Луиького НТУ, 2021. 278 с.

управління в глобальних, регіональних і місцевих виробничозбутових ланцюгах реалізації ІТ-послуг для країн Південної Африки [13]. Не зважаючи на багатогранність підходів учених до вивчення питань взаємодії компаній ІТ-бізнесу на міжнародних ринках, відзначаємо недостатність уваги щодо регіональних аспектів його здійснення, адже в сучасних умовах посилення тенденцій централізації та подальшого поширення пандемії, дана проблематика вимагає додаткового дослідження.

Цілі статті. Метою дослідження $є$ виокремлення регіональних аспектів IT-бізнесу, що здійснюється в межах міжнародних стратегічних альянсів.

Виклад основного матеріалу. IT-бізнес $є$ таким, що характеризується динамічним розвитком впродовж останнього десятиліття. Незважаючи на той факт, що у 2020 році витрати на IT зазнали серйозного удару через поширення пандемії COVID19, у 2021 році прогнозується їх зростання на 9,5\% із загальними витратами близько 4,2 трлн дол США. Станом на 2021 рік на регіон США припадає понад $34 \%$ світової частки ринку IКТ, на регіон СС - близько $15 \%$, на Китай - 11\%, значно менше на регіони Близького Сходу та Африки [14]. Воднораз, саме ринок IКТ на Близькому Сході буде зростати після пандемії найвищими темпами, що буде зумовлено низкою ініціатив зі сторони урядів у сферах цифрової трансформації та прийняття компаніями таких революційних технологій як штучний інтелект i інтернет речей. Окрім цього, перспективною вважається розробка портфеля послуг IКТ для корпорацій, зокрема програм для монетизації інвестицій в мережу 5G, хмарні обчислення та центри обробки даних, кібербезпека, ITекосистеми, блокчейн, промислові роботи тощо [15].

Прогнозована динаміка витрат на IT-бізнес у світі в найближчі роки зведена нами на рис. 1.

Україна прагне до інтеграції з СС, тому цікавим буде вивчення регіонального розподілу кількості міжнародних стратегічних альянсів і виділенням тенденції їх формування (табл. 1). 
Економічні науки: збірник наукових прачь Луцького національного технічного університету. Серія "Регіональна економіка". Випуск 18 (71). Редкол.: відп. ред. д.е.н., професор Л.Л. Ковальська. Луцьк: ІВВ Луцького НТУ, 2021. 278 с.

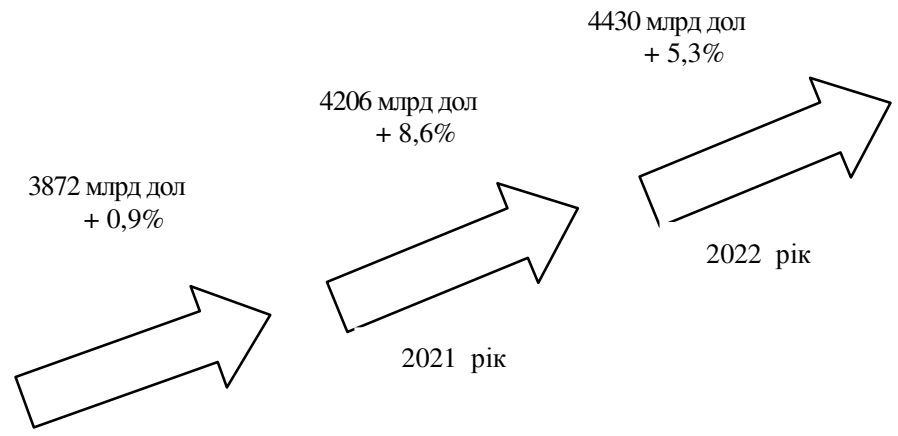

2020 рік

Рис. 1. Як змінюватимуться витрати на ІТ-бізнес у світі в період 2020-2022 років [16]

Таблиця 1

Стратегічні альянси на європейському ринку: регіональний розподіл у період, що передує поширенню пандемії COVID-19 $[17$, с. 51]

\begin{tabular}{|l|c|c|}
\hline \multicolumn{1}{|c|}{ Країна } & $\begin{array}{c}\text { Усереднене значення } \\
\text { кількості МСА }\end{array}$ & $\begin{array}{c}\text { Усереднене значення } \\
\text { кількості ССА }\end{array}$ \\
\hline Австрія & 25,11 & 9,22 \\
\hline Бельгія & 39,11 & 15,33 \\
\hline Болгарія & 40,33 & 2,28 \\
\hline Кіпр & 1,11 & 0,50 \\
\hline Чехія & 10,11 & 4,33 \\
\hline Данія & 21,56 & 7,17 \\
\hline Естонія & 2,44 & 0,56 \\
\hline Фінляндія & 34,33 & 11,22 \\
\hline Франція & 208,11 & 64,77 \\
\hline Німеччина & 290,88 & 66,38 \\
\hline Греція & 7,61 & 3,33 \\
\hline Угорщина & 22,44 & 10,06 \\
\hline Ірландія & 24,94 & 7,83 \\
\hline Італія & 103,27 & 0,44 \\
\hline Латвія & 1,50 & 1,00 \\
\hline Литва & 2,33 & 3,77 \\
\hline Люксембург & 9,00 & \\
\hline
\end{tabular}


Економічні науки: збірник наукових праць Луцького національного технічного університету. Серія "Регіональна економіка". Випуск 18 (71). Редкол.: відп. ред. д.е.н., професор Л.Л. Ковальська. Луиьк: ІВВ Луиького НТУ, 2021. 278 с.

Продовження таблиці 1

\begin{tabular}{|l|c|c|}
\hline Мальта & 0,33 & 0,22 \\
\hline Нідерланди & 114,67 & 32,61 \\
\hline Норвегія & 124,78 & 12,56 \\
\hline Польща & 22,00 & 9,94 \\
\hline Португалія & 9,44 & 4,28 \\
\hline Румунія & 43,67 & 3,61 \\
\hline Словаччина & 3,67 & 2,17 \\
\hline Словенія & 1,22 & 0,39 \\
\hline Іспанія & 48,83 & 20,89 \\
\hline Швеція & 61,67 & 21,28 \\
\hline Туреччина & 80,22 & 5,22 \\
\hline Великобританія & 422,72 & 79,61 \\
\hline
\end{tabular}

Результати показали наявність тенденції децентралізації у формуванні європейського ринку стратегічних альянсів у період, що передує поширенню пандемії COVID-19. Практично для усіх досліджуваних країн усереднені значення кількості ССА значно нижчі за усереднені значення кількості МСА. Тобто компанії європейських країн більшою мірою орієнтовані на створення стратегічних альянсів 3 компаніями інших регіонів світу.

В період поширення пандемії COVID-19 для мотивування створення та розвитку міжнародних стратегічних альянсів у ITсфері особливу увагу слід приділяти таким факторам як суміжність високотехнологічних галузей та секторів партнерів за бізнесом із врахуванням умов поширення COVID-19, суміжність стратегічних цілей партнерів до і після поширення COVID-19, взаємозамінність методів і форм роботи на ринку залежно від умов поширення COVID-19, швидкість диверсифікації бізнесу відносно поширення пандемії та введених режимів карантинних обмежень у країнах партнерів, відповідність внеску партнерів масштабам бізнесу під час пандемії, посилення оперативної інтеграції у міру розвитку стратегічного альянсу [3].

Висновки. Поглиблення досліджень в напрямку вивчення регіональних аспектів, які супроводжують процеси створення та розвитку міжнародних стратегічних альянсів $€$ 
Економічні науки: збірник наукових праць Луцького національного технічного університету. Серія "Регіональна економіка". Випуск 18 (71). Редкол.: відп. ред. д.е.н., професор Л.Л. Ковальська. Луиьк: ІВВ Луиького НТУ, 2021. 278 с.

важливим 3 тих причин, що дозволяє уточнити розподіл ринку інформаційно-комунікаційних технологій за регіонами світу, регіональний розподіл стратегічних альянсів, а також тенденції формування такого розподілу.

Критичний аналіз наукових публікацій вітчизняних i зарубіжних учених дозволяє розкрити особливості співпраці міжнародних стратегічних альянсів у сфері IT-бізнесу, і вказує на вагомість ролі регіональних альянсів, зокрема у формуванні IT-бізнесу компаній з різних регіонів світу.

Подальший аналіз показників розвитку IT-бізнесу в період поширення пандемії COVID-19 дозволив виявити ключову роль компаній МСА 3 регіону США, країн ЄС і Китаю. В той самий час перспективність розвитку цього ринку для компаній країн Близького Сходу є найкращою, що буде досягнуто завдяки поширенню ініціатив зі сторони урядів у сферах цифрової трансформації та прийняття компаніями таких революційних технологій як штучний інтелект i iнтернет речей, розробки портфеля послуг IKT для корпорацій. Аналіз регіонального розподілу стратегічних альянсів в країнах ЄС виявив тенденцію децентралізації у формуванні європейського ринку стратегічних альянсів у період, що передує поширенню пандемії COVID-19.

Для подальшого мотивування створення та розвитку міжнародних стратегічних альянсів у IT-бізнесі запропоновано враховувати фактори, що вказують на суміжність високотехнологічних галузей та секторів партнерів за бізнесом, суміжність стратегічних цілей партнерів, взаємозамінність методів i форм роботи на регіональних ринках тощо iз врахуванням умов поширення COVID-19.

Подальші дослідження пропонується спрямовувати на пошук механізмів удосконалення взаємодії партнерських відносин в межах міжнародних стратегічних альянсів у сфері IT-бізнесу 3 метою вивчення можливостей покращення співпраці.

\section{Список бібліографічного опису}

1. Ніжейко К. Міжнародні технологічні альянси в ІТ-сфері. Зовнішня торгівля: економіка, фінанси, право. 2021. № 3. С. 52-63. 
Економічні науки: збірник наукових праць Луцького національного технічного університету. Серія "Регіональна економіка". Випуск 18 (71). Редкол.: відп. ред. д.е.н., професор Л.Л. Ковальська. Луиьк: ІВВ Луцьького НТУ, 2021. 278 с.

2. Морозова I.В., Чернова О.В. Стратегічні альянси як феномен глобальної економіки. Приазовський економічний вісник. 2020. Випуск 1 (18). C. 14-19.

3. Кривов'язюк I.B. Фактори успіху міжнародних стратегічних альянсів у IT-сфері в умовах поширення COVID-19. Економічний форум. 2021. № 4.

4. Amankwah-Amoah J., Khan Z. \& Wood, G. COVID-19 and business failures: The paradoxes of experience, scale, and scope for theory and practice. European Management Journal. 2020. Vol. 39. Issue 2. PP. 179-184.

5. Дугінець Г., Ніжейко К. Міжнародні технологічні альянси: співпраця компаній в IT-сфері. Зовнішня торгівля: економіка, фінанси, право. 2020. № 6. С. 35-47.

6. Габрелян А. Ю. Особливості функціонування міжнародних стратегічних альянсів в IT-сфері. Правові системи. Науково-практичний електронний журнал. 2018. № 1/2. С. 469-478.

7. Орлов В. М., Петрашевська А. Д., Драган К. Ю., Статірова К. В. Фактори формування стратегічних альянсів. Бізнес Інформ, 2019. № 12. С. 76-81.

8. Максименко I. Я., Єфімова М. О. Особливості формування стратегічних альянсів на міжнародному та українському ринках. Ефективна економіка. 2019. № 12. URL: http://www.economy.nayka.com.ua/?op=1\&z=7485 (дата звернення: 10.09.2021).

9. Strilchuk R., Kryvovyazyuk I. Market of information and communication technologies and place of Ukraine in it. Економічний форум. 2017. №2. C. 152-157.

10. Abraha D. and Hyder A.S. Transformation of Strategic Alliances in Emerging Markets. Emerald Publishing Limited, Bingley, 2021. 163 p.

11. Trang S., Mandrella M., Marrone M., Kolbe L. M. Co-creating business value through IT-business operational alignment in inter-organisational relationships: empirical evidence from regional networks. European Journal of Information Systems. 2021. DOI: 10.1080/0960085X.2020.1869914.

12. Panda S. Strategic IT-business alignment capability and organizational performance: roles of organizational agility and environmental factors. Journal of Asia Business Studies. 2021. Vol. ahead-of-print. https://doi.org/10.1108/JABS-09-20200371.

13. Keijser Ch., Belderbos R., Goedhuys M. Governance and learning in global, regional, and local value chains: The IT enabled services industry in South Africa. World Development. 2021. Volume 141. 105398. https://doi.org/10.1016/j.worlddev.2021.105398.

14. Alsop T. Yearly growth forecast IT spending worldwide 2016-2022 / 2021 Statista. URL: https://www.statista.com/statistics/268940/percent-growth-in-itspending-worldwide-by-segment/ (дата звернення: 10.09.2021).

15. Middle East ICT Market Outlook, 2021 - Innovative Business Models Spur Growth / 2021 Research and Markets. URL: https://www.researchandmarkets.com/reports/5333041/middle-east-ict-marketoutlook-2021-innovative (дата звернення: 10.09.2021). 
Економічні науки: збірник наукових праць Луцького національного технічного університету. Серія "Регіональна економіка". Випуск 18 (71). Редкол.: відп. ред. д.е.н., професор Л.Л. Ковальська. Луиьк: ІВВ Луиького НТУ, 2021. 278 с.

16. Gartner Forecasts Worldwide IT Spending to Grow 9\% in 2021. Technology Spending Enters a New Build Budget Phase. STAMFORD, Conn., July 14, 2021. Press Release / 2021 Gartner, Inc. URL: https://www.gartner.com/en/newsroom/press-releases/2021-07-14-gartner-forecastsworldwide-it-spending-to-grow-9-percent-2021 (дата звернення: 10.09.2021).

17. Alhorr H. S., Boal K., Cowden B. J. Regional economic integration and international strategic alliances: evidence from the EU. Multinational Business Review, 2012. Vol. 20. № 1. P. 44-66.

\section{References}

1. Nizheyko K. Mizhnarodni tekhnolohichni al'yansy v IT-sferi. Zovnishnya torhivlya: ekonomika, finansy, pravo - Foreign trade: economics, finance, law, 2021, no. 3, pp. 52-63. [in Ukrainian].

2. Morozova I.V., Chernova O.V. Stratehichni al'yansy yak fenomen hlobal'noyi ekonomiky. Pryazovs'kyy ekonomichnyy visnyk - Priazovsky Economic Bulletin, 2020, no. 1 (18), pp. 14-19. [in Ukrainian].

3. Kryvovyazyuk I.V. Success factors of international strategic alliances alliances in the IT sphere in the conditions of COVID-19 spreading. Ekonomichnyy forum - Economic forum, 2021, vol. 1 (4). [in Ukrainian].

4. Amankwah-Amoah J., Khan Z. \& Wood, G. COVID-19 and business failures: The paradoxes of experience, scale, and scope for theory and practice. European Management Journal, 2020, Vol. 39, Issue 2, pp. 179-184.

5. Duhinets' H., Nizheyko K. Mizhnarodni tekhnolohichni al'yansy: spivpratsya kompaniy $\mathrm{v}$ IT-sferi. Zovnishnya torhivlya: ekonomika, finansy, pravo - Foreign trade: economics, finance, law, 2020, no. 6, pp. 35-47. [in Ukrainian].

6. Habrelyan A.Yu. Osoblyvosti funktsionuvannya mizhnarodnykh stratehichnykh al'yansiv v IT-sferi. Pravovi systemy - Legal systems, 2018, no. 1/2, pp. 469-478. [in Ukrainian].

7. Orlov V.M., Petrashevs'ka A.D., Drahan K.Yu., Statirova K.V. Faktory formuvannya stratehichnykh al'yansiv. Biznes Inform - Business Inform, 2019, no. 12, pp. 76-81. [in Ukrainian].

8. Maksymenko I.Ya., Yefimova M.O. Osoblyvosti formuvannya stratehichnykh al'yansiv na mizhnarodnomu ta ukrayins'komu rynkakh. Efektyvna ekonomika, 2019, no. 12. URL: http://www.economy.nayka.com.ua/?op=1\&z=7485 (accessed 10.09.2021). [in Ukrainian].

9. Strilchuk R.M., Kryvovyazyuk I.V.Market of information and communication technologies and place of Ukraine in it. Ekonomichnyy forum Economic forum, 2017, no. 2, pp. 152-157. [in Ukrainian].

10. Abraha D. and Hyder A.S. Emerging Markets: European Transition Economies, Transformation of Strategic Alliances in Emerging Markets, 2021, vol. 1, Emerald Publishing Limited, Bingley, pp. 145-157.

11. Trang S., Mandrella M., Marrone M. \& Kolbe L. M. Co-creating business value through IT-business operational alignment in inter-organisational 
Економічні науки: збірник наукових праць Луцького національного технічного університету. Серія "Регіональна економіка". Випуск 18 (71). Редкол.: відп. ред. д.е.н., професор Л.Л. Ковальська. Луцьк: ІВВ Луцького НТУ, 2021. 278 с.

relationships: empirical evidence from regional networks. European Journal of Information Systems. 2021. DOI: 10.1080/0960085X.2020.1869914.

12. Panda S. Strategic IT-business alignment capability and organizational performance: roles of organizational agility and environmental factors. Journal of Asia Business Studies. 2021. Vol. ahead-of-print. https://doi.org/10.1108/JABS-092020-0371.

13. Keijser Ch., Belderbos R., Goedhuys M. Governance and learning in global, regional, and local value chains: The IT enabled services industry in South Africa. World Development. 2021. Volume 141. 105398. https://doi.org/10.1016/j.worlddev.2021.105398.

14. Alsop T. Yearly growth forecast IT spending worldwide 2016-2022 / 2021 Statista. URL: https://www.statista.com/statistics/268940/percent-growth-in-itspending-worldwide-by-segment/ (дата звернення: 10.09.2021).

15. Middle East ICT Market Outlook, 2021 - Innovative Business Models Spur Growth / 2021 Research and Markets. URL: https://www.researchandmarkets.com/reports/5333041/middle-east-ict-marketoutlook-2021-innovative (дата звернення: 10.09.2021).

16. Gartner Forecasts Worldwide IT Spending to Grow 9\% in 2021. Technology Spending Enters a New Build Budget Phase. STAMFORD, Conn., July 14, 2021. Press Release / 2021 Gartner, Inc. URL: https://www.gartner.com/en/newsroom/press-releases/2021-07-14-gartner-forecastsworldwide-it-spending-to-grow-9-percent-2021 (дата звернення: 10.09.2021).

17. Alhorr H. S., Boal K., Cowden B. J. Regional economic integration and international strategic alliances: evidence from the EU. Multinational Business Review, 2012. Vol. 20. № 1. P. 44-66.

DOI: https://doi.org/10.36910/2707-6296-2021-18(71)-11

УДК 331.109

Куцай Н.С., к.е.н., доцент

Луцький національний технічний університет

\section{УПРАВЛІННЯ КОНФЛІКТАМИ НА ПІДПРИЄМСТВІ}

У статті розглянуто основні причини та особливості впливу конфлікту в трудовому колективі на підприємстві, визначено елементи конфліктних ситуацій, проведено характеристику факторів, які впливають на рівень конфліктних ситуацій на підприємстві та розглянуто причини їх виникнення. Запропоновано кроки для ефективного управління вирішення конфліктів на підприємстві. 